\title{
Acid Stability of Anti-Helicobacter pyroli IgY in Aqueous Polyol Solution
}

\author{
Kyong Ae Lee*, Sung Keun Chang, Yoon Jin Lee, Jong Hwa Lee ${ }^{\dagger}$ and Nan Sook Koo \\ Division of Applied Science, College of Natural Science, Soonchunhyang University, Asan 337-600, Korea \\ 'Lee \& Joe Biotech, Asan 337-600, Korea \\ Department of Food and Nutrition, College of Science, Daejeon University, Daejeon 300-716, Korea
}

Received 10 July 2002, Accepted 5 August 2002

IgY was separated from a hen's egg yolk that was immunized with Helicobacter pyroli. The anti-H. pyroli IgY activity at acidic pH and the suppressive effect of polyol on acid-induced inactivation of IgY were investigated. Sorbitol and xylitol were used as polyols. IgY was quite stable at pH 5 7. Irreversible inactivation of IgY was observed at $\mathrm{pH}$ below 4 , and proceeded rapidly at $\mathrm{pH}$ below 3. The acid stability of IgY was enhanced in the presence of $30 \%$ sorbitol or above. In a $50 \%$ aqueous sorbitol solution, an acid-induced inactivation was almost completely suppressed at pH 3. However, the improvement of IgY activity was not observed in the aqueous xylitol solution. IgY showed almost the same activity as native IgY when sucrose was substituted for sorbitol. On the other hand, the xylitol replacement with sucrose did not enhance the acid stability of IgY. The acid-induced inactivation of IgY was related to tryptophyl fluorescence. Fluorescence emission spectra suggested that structural changes near the tryptophan residues may occur under acidic conditions. An increase in sorbitol concentration induced a blue shift. The fluorescence emission of IgY in a $50 \%$ sorbitol solution had a peak at $330 \mathrm{~nm}$, which was the same emission peak that was exhibited by native IgY. Sorbitol could, therefore, be used as a good stabilizer of IgY under acidic conditions.

Keywords: Acid stability, Helicobacter pyroli, IgY, Sorbitol, Xylitol

\section{Introduction}

Helicobacter pyroli $(H$. pyroli) is a key pathogen of chronic gastritis, duodenal ulcer, and gastric ulcer. Infection with $H$. pyroli generally occurs in children before the age of 10 years

*To whom correspondence should be addressed.

Tel: 82-41-530-1262 Fax: 82-41-530-1264

E-mail: kaelee@sch.ac.kr
(Ernst and Gold, 2000). In developed countries, 25 50\% of the population carry $H$. pyroli. The prevalence of infection in developing country is higher, ranging from 70 to $90 \%$ (Dunn et al, 1997). Although $H$. pyroli is sensitive to various antibiotics, antibacterial agents alone have mostly failed to eradicate H. pyroli (Chiba et al., 1992). Moreover, increased occurrences of antibiotics-resistant strains of $H$. pyroli have become a problem (Ling et al., 1996). An antibody could confer protection against $H$. pyroli. Therefore, oral passive immunization by an antibody may be useful in preventing $H$. pyroli infection.

Polyclonal antibodies are usually produced by mammalian sera. However, collecting sera requires a lot of care, and these antibodies are very expensive and limited so that another antibody source should be investigated. A hen's egg can be an effective antibody supplier. Only one class of immunoglobulins, $\operatorname{IgG}$, among the immunoglobulins in the hen's sera can be selectively transported in large quantities and efficiently accumulated in an egg yolk (Rose et al., 1974; Rose and Orlands, 1981). Chicken housing is inexpensive and egg collection is noninvasive. Moreover, isolation of IgG-type immunoglobulins is comparatively simple. An egg yolk contains about $1 \%$ IgG-type immunoglobulins (Lösch et al, 1988); therefore, it is a rich antibody source. The yolk immunoglobulins are slightly different from mammalian IgG in their molecular size, isoelectric point, binding ability with protein $A$ or $G$, activation ability of the mammalian complement, and domain structure (Higgins, 1975; Benedict, 1979; Parvari at al., 1989; Reynaud et al., 1989; Kwack, 2000). Therefore, the immunoglobulins in yolk are now called IgY (named by Leslie and Clem, 1969).

Recent investigations, concerning the passive immunity by oral administration of IgY, have increased interest in IgY. IgY decreased the incidence of diarrhea, due to the rotavirus or $E$. coli (Yoelken et al., 1988; OFarrelly et al., 1992; Hatta et al., 1993). IgY also conferred protection against dental caries that are formed by Streptococcus mutans (Otake et al., 1991; Hatta et al., 1997; Smith et al., 2001). Yang et al. (1997) showed that IgY could specifically recognize digestive system cancer, 
which indicates its potential use in cancer prevention. Such protective effects have increased interest in applying IgY to pharmaceutical and food products. However, the reduced stability of IgY under acidic conditions are limited for expanded use in food products. Therefore, the stability of IgY at low $\mathrm{pH}$ should be improved in order to enhance its use.

This research was performed to investigate the production and separation of anti- $H$. pyroli $\operatorname{IgY}$, and possible stabilizing effects of polyols on IgY under acidic conditions.

\section{Materials and Methods}

Antigen preparation The $H$. pyroli strain ATCC 43504 was grown in broth culture at $37^{\circ} \mathrm{C}$ for $36 \mathrm{~h}$, then the cells were harvested. One gram of the harvested cells was suspended in $50 \mathrm{ml}$ of phosphatebuffered saline (PBS, $\mathrm{pH}$ 7.2). After sonication, the supernatant was separated by centrifugation at $10,000 \times g$ for $15 \mathrm{~min}$. The supernatant that was obtained by the additional centrifugation at $100,000 \times g$ for 30 min was then used as an antigen.

Immunization of hens Hens (Hy-Line Brown), 21-wk-old, were used for immunization and egg production. One hundred $\mu \mathrm{l}$ of a $0.1 \%$ antigen solution in PBS was emulsified with an equal volume of complete Freund's adjuvant (Difco Co., Detroit, USA), then intramuscularly injected into the hens. Two booster injections, each with $100 \mu \mathrm{g}$ of antigen and incomplete Freund's adjuvant (Difco Co., Detroit, USA), were intramuscularly given at 2 and 4 weeks after the first injection. The eggs were collected for IgY separation after a second booster injection.

Crude IgY preparation Crude IgY was prepared from an egg yolk by three separation methods. (1) The water dilution method: IgY was separated by the method presented by Akita and Nakai (1993). Ten $\mathrm{ml}$ of egg yolk was diluted $60 \mathrm{ml}$ with deionized water. The supernatant, crude IgY solution, was isolated by centrifugation. (2) The $\lambda$-carrageenan method: IgY was isolated by the procedure that is described by Hatta et al. (1990). Ten ml of egg yolk was diluted to $100 \mathrm{ml}$ with $0.15 \% \lambda$-carrageenan (Sigma Chemical Co., St. Louis, USA). The resulting solution was held at room temperature for $30 \mathrm{~min}$. The supernatant, crude IgY solution, was separated by centrifugation. (3) The polyethylene glycol method: IgY was isolated by the method of Polson et al. (1980). Briefly, $10 \mathrm{ml}$ of egg yolk was diluted to $50 \mathrm{ml}$ with PBS. Polyethylene glycol 6000 (PEG 6000) was added to a concentration of 3.5\% and centrifuged. PEG 6000 was added to the supernatant to give $12 \%$. The pellet that was obtained by centrifugation was redissolved in $5 \mathrm{ml}$ of PBS, and ammonium sulfate was added to a concentration of $50 \%$. The protein precipitate, IgY, was collected by centrifugation and resuspended in $1 \mathrm{ml}$ of PBS. The crude IgY solution was extensively dialyzed against PBS.

The crude IgY solution that was prepared by the three separation methods was stored at $4^{\circ} \mathrm{C}$ for further analysis.

Acid treatment The $\mathrm{pH}$ of the $0.2 \% \operatorname{IgY}$ solution in saline in the presence of 0 50\% polyol was adjusted to $\mathrm{pH} 2 \sim 7$ with $\mathrm{HCl}$. The resulting solution was incubated at $37^{\circ} \mathrm{C}$. After incubation at each $\mathrm{pH}$, the solution was neutralized with PBS that contained $0.05 \%$ tween 20 (PBS-T). ELISA examined the antibody activity.

Protein determination The protein concentration of antigen or the crude IgY solution was determined with a protein assay kit (Bio-Rad Co., Hercules, USA). Bovine serum albumin was used as the standard.

IgY determination The crude IgY concentration was determined by measuring the absorbance at $280 \mathrm{~nm}$, based on 13.6 as extinction coefficient at $280 \mathrm{~nm}$ of a $1 \% \mathrm{IgY}$ solution (Tenenhouse and Deutsch, 1966).

The specific $\operatorname{IgY}$ concentration in crude IgY was determined by immunoprecipitation (Japanese Biochemical Society, 1986). Then $0.5 \mathrm{ml}$ of the crude IgY solution and $1 \mathrm{ml}$ of a $0.01 \%$ antigen solution in PBS were added to the same tube and incubated overnight at $37^{\circ} \mathrm{C}$. The supernatant was separated by centrifugation $(3,000 \times \mathrm{g}, 30 \mathrm{~min})$, and the absorbance was measured at $280 \mathrm{~nm}$. The specific IgY concentration was calculated as follows:

$$
\begin{aligned}
& \text { Specific } \operatorname{IgY}(\%)= \\
& \frac{\text { absorbance without antigen }- \text { absorbance with antigen }}{\text { absorbance without antigen }} \times 100
\end{aligned}
$$

ELISA Noncompetitive ELISA assessed the IgY antibody activity. A polystyrene plate (Nunc Co., Roskilde, Denmark) was coated with $0.1 \mathrm{ml}$ of the $0.01 \%$ antigen solution in PBS for $2 \mathrm{~h}$ at $37^{\circ} \mathrm{C}$. The plate was then washed with PBS-T, then appropriatelydiluted native or acid-treated IgY was added. After incubating for $2 \mathrm{~h}$, the wells were washed with PBS-T, and $0.1 \mathrm{ml}$ of an alkaline phosphatase-conjugated rabbit anti-chicken IgG (Sigma Chemical Co., St. Louis, USA) was added. After incubating for an additional $2 \mathrm{~h}$, the plate was washed with PBS-T, then $0.1 \mathrm{ml}$ of the substrate solution $(0.01 \%$ p-nitrophenyl phosphate in diethanolamine buffer at $\mathrm{pH} 9.8$ ) was added. After further incubation for $30 \mathrm{~min}, 5 \mathrm{~N}$ $\mathrm{NaOH}$ was added to stop the reaction. The absorbance was measured at $405 \mathrm{mn}$ on a microplate reader (Molecular Device Co., Sunnyvale, USA). Relative IgY activity (B/Bo) was calculated as absorbance at $405 \mathrm{~nm}$ of the acid-treated $\operatorname{IgY} \div$ absorbance at $405 \mathrm{~nm}$ of native $\mathrm{IgY}$.

SDS-PAGE SDS-PAGE was performed by the method of Weber and Osborn (1969) using 10\% acrylamide gel. The protein was stained with Coomassie blue R-250 and destained with $10 \%$ acetic acid.

Fluorescence measurement The fluorescence emission spectra of IgY were measured by a spectrofluorometer (Jasco, Tokyo, Japan). The $0.02 \%$ IgY solutions in saline were excited at $296 \mathrm{~nm}$, then the emission peak was measured.

\section{Results}

Separation of IgY $\operatorname{IgY}$ was separated by the water dilution, $\lambda$-carrageenan, or polyethylene glycol methods. SDS-PAGE showed a $64-\mathrm{kDa}$ band (II) that corresponded to the heavy chain of IgY and a $25-\mathrm{kDa}$ band (IV) that corresponded to the light chain of $\operatorname{IgY}$ (Fig. 1). Water-soluble protein that was 


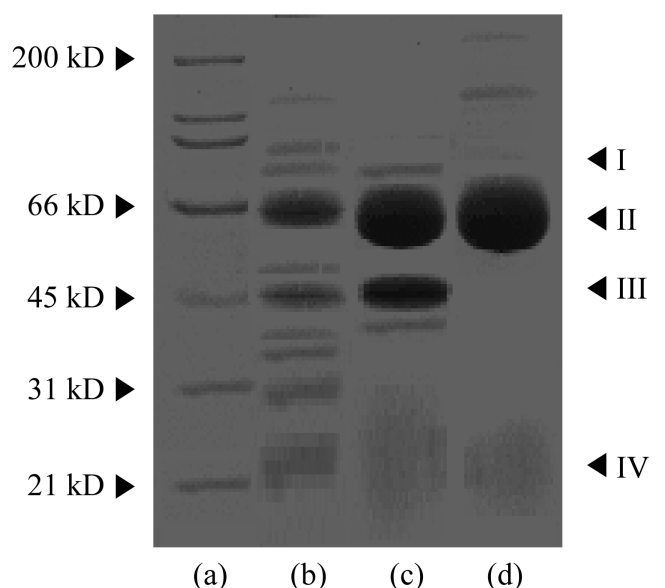

(a) (b) (c) (d)

Fig. 1. SDS-PAGE patterns of separated IgY. IgY was separated with water dilution method (WD), $\lambda$-carrageenan method $(\lambda C)$ and polyethylene glycol method (PEG). (a) marker, (b) WD, (c) $\lambda \mathrm{C}$, (d) PEG

separated by the $\lambda$-carrageenan method contained $\alpha$-(I) and $\beta$ livetin (III), as well as $\gamma$-livetin, known as IgY (Fig. 1). SDSPAGE indicated that comparatively pure IgY was isolated by the polyethylene glycol method. Yield, purity, and specific IgY content of the three separation methods are compared in Table 1. The polyethylene glycol method gave the highest yield and purity, followed by $\lambda$-carrageenan method; the water dilution method showed the lowest yield and purity. IgY that was isolated by the polyethylene glycol method also contained more specific IgY than other methods. These results indicate that the polyethylene glycol method (among the three separation methods) was the most efficient in IgY separation. Therefore, IgY that was prepared by the polyethylene glycol method was used for stability determination.

IgY activity under acidic conditions The stability of IgY at each $\mathrm{pH}$ is shown in Fig. 2. IgY showed good stability at $\mathrm{pH} 5 \sim 7$ after incubating $24 \mathrm{~h}$ at each respective $\mathrm{pH}$. IgY was inactivated irreversibly at $\mathrm{pH}$ below 4 . IgY inactivation was irreversible. The time-dependent changes of IgY activity at acidic $\mathrm{pH}$ are presented in Fig. 3. When incubating at each $\mathrm{pH}$ for $4 \mathrm{~h}, \mathrm{IgY}$ lost antibody activity at $\mathrm{pH} 4$ or below. The

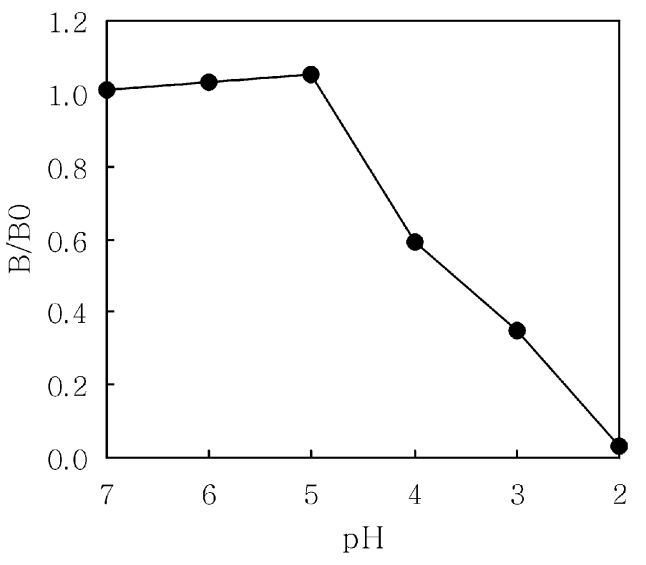

Fig. 2. Antibody activity of $\mathrm{IgY}$ after incubating at different $\mathrm{pH}$. IgY was incubated at $\mathrm{pH} 7 \sim 2$ for $24 \mathrm{~h}$. B/Bo was calculated as absorbance of acid-treated $\operatorname{IgY} \div$ absorbance of native $\operatorname{IgY}$. Absorbance was measured at $405 \mathrm{~nm}$.

antibody activity was significantly reduced (up to 50\%) at $\mathrm{pH}$ below 3. IgY almost completely lost its activity by incubating for $4 \mathrm{~h}$ at $\mathrm{pH}$ 2. The most noticeable loss in antibody activity was observed during the first $30 \mathrm{~min}$.

To examine the structural changes of $\operatorname{IgY}$ after acid treatment, the fluorescence emission peak was measured. The tryptophan residues of $\operatorname{IgY}$ were excited at $296 \mathrm{~nm}$; this reflected the structural changes near the tryptophan residues. Figure 4 shows that the acid treatment of $\operatorname{IgY}$ caused a red shift of the fluorescence emission peak, due to the change of the local environment around the tryptophan residues. After incubating at $\mathrm{pH} 7$ for $4 \mathrm{~h}, \operatorname{IgY}$ had an emission peak at $330 \mathrm{~nm}$, which was the same peak as native IgY. The emission peak for IgY changed from $330 \mathrm{~nm}$ to $337 \mathrm{~nm}$ or $338 \mathrm{~nm}$ after incubating at $\mathrm{pH} 3$ or $\mathrm{pH} 2$ for $4 \mathrm{~h}$.

\section{Suppressive effects of polyols on acid-induced inactivation} The IgY activity at $\mathrm{pH} 3$ in the presence of polyol is shown in Fig. 5. Sorbitol and xylitol were used as polyols. Sorbitol suppressed IgY inactivation in a concentration-dependent manner. The IgY activity was significantly increased in the presence of $30 \%$ sorbitol or above. Fifty percent sorbitol showed almost complete suppression of acid-induced

Table 1. Separation efficiency of three isolation methods

\begin{tabular}{ccccc}
\hline separation method & protein $(\mathrm{mg} / \mathrm{mL})$ & $\operatorname{IgY}^{\mathrm{e}}(\mathrm{mg} / \mathrm{mL})$ & purity $^{\mathrm{d}}(\%)$ & specific $\operatorname{IgY}(\%)$ \\
\hline WD $^{\mathrm{a}}$ & 5.5 & 1.1 & 20.0 & 10.7 \\
$\mathrm{C}^{\mathrm{b}}$ & 5.8 & 1.4 & 24.1 & 14.1 \\
PEG $^{\mathrm{c}}$ & 6.9 & 2.6 & 37.1 & 23.5 \\
\hline
\end{tabular}

\footnotetext{
${ }^{\mathrm{a}}:$ water dilution method

$\mathrm{b}: \lambda$-carrageenan method

${ }^{\mathrm{c}}$ : polyethylene glycol method

${ }^{d}$ : purity was calculated as conc. of $\operatorname{IgY} \div$ conc. of protein $\times 100$

e : crude IgY
} 


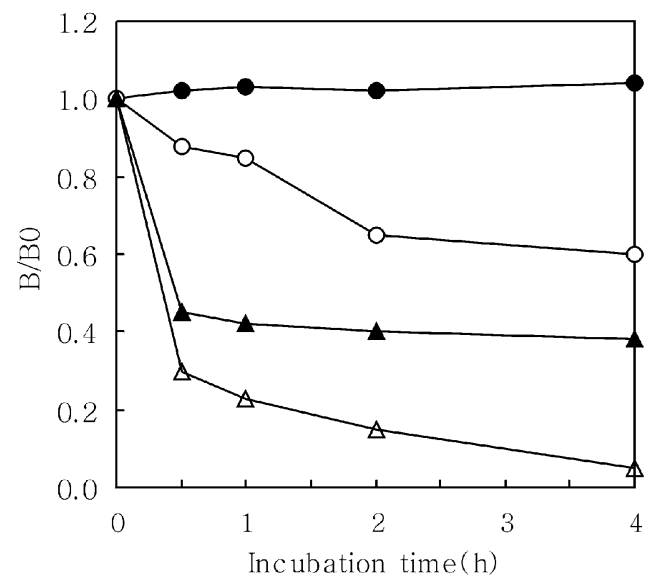

Fig. 3. Time-dependent changes of $\operatorname{IgY}$ activity under acidic conditions. IgY was incubated at $\mathrm{pH} 7(\mathbf{O}), \mathrm{pH} 4(\bigcirc), \mathrm{pH} 3(\boldsymbol{\Delta})$ or $\mathrm{pH} 2(\triangle)$. B/Bo was calculated as absorbance of acid-treated IgY $\div$ absorbance of native IgY. Absorbance was measured at $405 \mathrm{~nm}$.

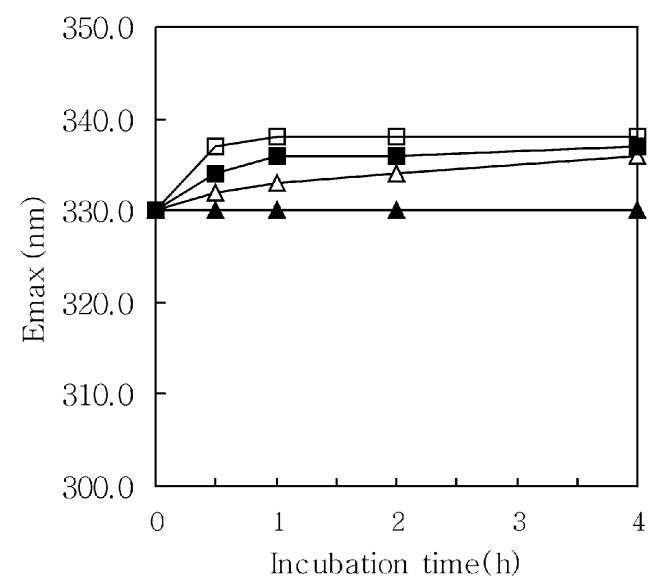

Fig. 4. Fluorescence emission spectra of $\operatorname{IgY}$. IgY was incubated at $\mathrm{pH} 7(\boldsymbol{\Delta}), \mathrm{pH} 4(\triangle), \mathrm{pH} 3(\boldsymbol{\square})$ or $\mathrm{pH} 2(\square)$ for 4 h. Emax was the emission peak, when excited at $296 \mathrm{~nm}$.

inactivation at $\mathrm{pH} \mathrm{3}$; however, xylitol caused no increase in IgY activity.

At larger intakes, polyols generally have a laxative effect and are usually used in limited amounts, or in combination with sucrose. Therefore, the effect of sucrose substitution for sorbitol, or xylitol on IgY activity at $\mathrm{pH} 3$, was investigated (Fig. 6). IgY showed almost the same activity as native IgY when sorbitol was replaced by sucrose. However, the acidinduced inactivation of IgY was not enhanced by xylitol replacement with sucrose. Because the acid-induced inactivation was related to the tryptophyl fluorescence (Fig. 4), the fluorescence emission spectral changes by polyol or sucrose substitution for polyol were also examined (Fig. 7). The emission peak for IgY showed a blue shift with an increase in the sorbitol concentration. The emission peak for $\mathrm{IgY}$ in the $50 \%$ sorbitol solution was $330 \mathrm{~nm}$, which was the

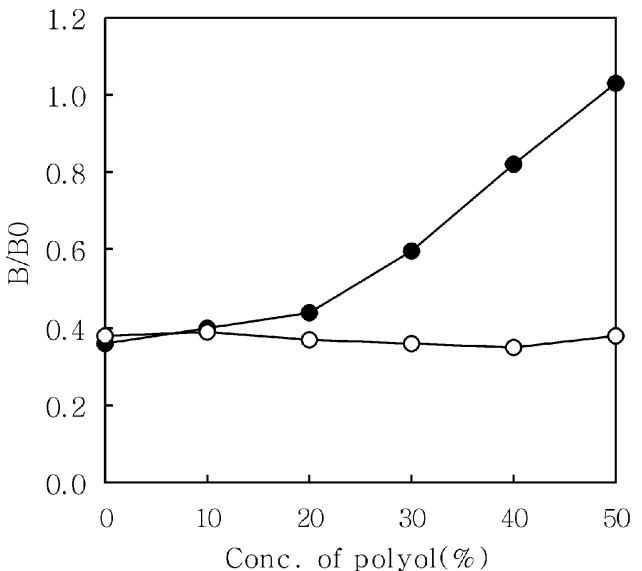

Fig. 5. Antibody activity of $\operatorname{IgY}$ in aqueous polyol solution. $\operatorname{IgY}$ was incubated with sorbitol $(\mathbf{O})$ or xylitol $(\bigcirc)$ at $\mathrm{pH} 3$. B/Bo was calculated as absorbance of $\operatorname{IgY}$ at $\mathrm{pH} 3 \div$ absorbance of native $\operatorname{IgY}$. Absorbance was measured at $405 \mathrm{~nm}$.

same peak that was exhibited by native IgY. Sorbitol replacement with sucrose had no effect on the emission peak. However, xylitol or xylitol replacement with sucrose did not cause a blue shift. These results suggest that sorbitol may inhibit structural changes near tryptophan residues by acidification, which results in the improvement of $\operatorname{IgY}$ stability.

\section{Discussion}

$H$. pyroli is a significant human pathogen. Up to $50 \%$ of the world's population is infected with $H$. pyroli (Goodwin et al., 1997). Several investigators reported the potential use of IgY in immunotherapy (OFarrelly et al., 1992; Yang et al., 1997; Smith et al., 2001); therefore, passive immunity by oral administration of IgY may be helpful to protect against $H$. pyroli. The reduced acid stability of IgY hindered its use for protection from $H$. pyroli. Therefore, the possible improvement of $\operatorname{IgY}$ stability at $\mathrm{pH} 3$ in a polyol solution was examined.

IgY showed an irreversible inactivation under acidic conditions (Fig. 2). A remarkable inactivation of IgY occurred at $\mathrm{pH}$ below 3 during the first $30 \mathrm{~min}$ (Fig. 3). Palmer et al. (1963) showed that the noncovalent bonds of rabbit IgG were disrupted under acidic conditions. According to the increase in positively-charged groups by acidification, the electrostatic interactions (including electrostatic repulsion) may be changed. These changes are attributable to the destruction of the noncovalent bonds.

The acid-induced inactivation of IgY suggests a decrease in the antigen-binding ability that is probably due to structural changes. Fluorescence emission spectrum is a useful tool for the investigation of structural changes (Cho and Song, 2000). Therefore, IgY fluorescence emission spectra, when excited at $296 \mathrm{~nm}$, were observed. The quenching effect on tryptophan 


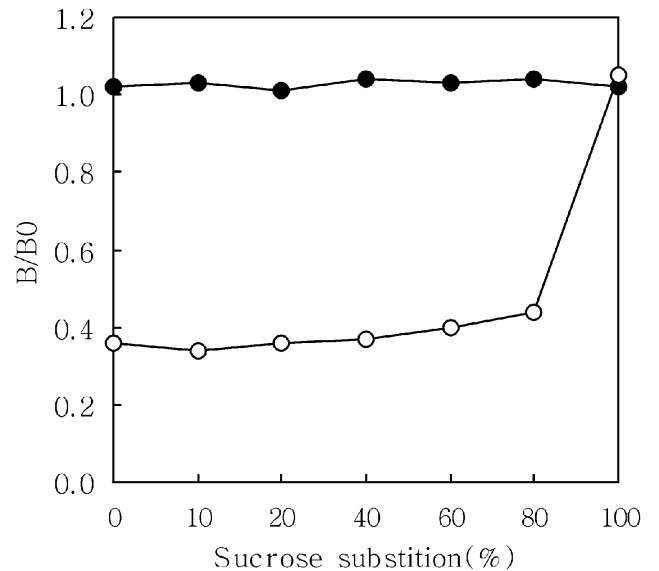

Fig. 6. Antibody activity of $\operatorname{IgY}$ in the presence of polyol in combination with $0 \sim 50 \%$ sucrose at $\mathrm{pH}$ 3. Sorbitol $(\mathbf{O})$ or xylitol $(\bigcirc)$ was used as polyol. Total sugar concentration was $50 \%$. B/Bo was calculated as absorbance of acid-treated $\operatorname{IgY}$ $\div$ absorbance of native IgY. Absorbance was measured at $405 \mathrm{~nm}$.

residues was gradually removed by acidification (Fig. 4). Disulfide bonds quench tryptophyl fluorescence of native immunoglobulin. The IgY primary sequence data indicates that IgY possesses intra- and intermolecular disulfide bonds, which confer quenching effects on tryptophan residues, such as mammalian IgG (Thompson et al., 1987; Parvari et al., 1988; Reynaud et al., 1989). This result, therefore, shows that the quenching effect is irreversibly removed by partial exposure of the tryptophan residue at low $\mathrm{pH}$. In contrast to mammalian IgG, IgY has a heavy chain with four constant domains and no hinge region, which gives considerable flexibility to antigen binding. There are regions in constant domains that contain proline and glycine residues, which act like a switching hinge and confer a limited flexibility on antigen-binding of IgY (Warr et al., 1995). This limited flexibility may decrease the antigen-binding activity of IgY, even when small structural changes are evident.

Polyols are often used for stabilizing protein. Sorbitol and xylitol (among polyols) are widely-used sugar substitutes, due to their usefulness for diabetics, reduced cariogenecity, and inhibition of bone resorption (Giese, 1993; Matilla et al., 1996). IgY activity at pH 3 was enhanced in $30 \%$ sorbitol or above, but xylitol did not increase the acid stability of $\operatorname{IgY}$ (Fig. 5). An increase in sorbitol concentration induced a gradual blue shift in the emission peak for IgY. The acidinduced inactivation of $\operatorname{IgY}$ was suppressed almost completely in a $50 \%$ sorbitol solution (Fig. 6). As indicated by several researchers (Gekko, 1981; Gekko and Timasheff, 1981), the preferential hydration of IgY may occur in an aqueous sorbitol solution; therefore, hydrophobic interactions around tryptophan residues would be strengthened. These changes might protect the partial exposure of tryptophan residues, which would result in stabilization of the $\operatorname{IgY}$ structure. However, xylitol could not effectively stabilize hydrophobic
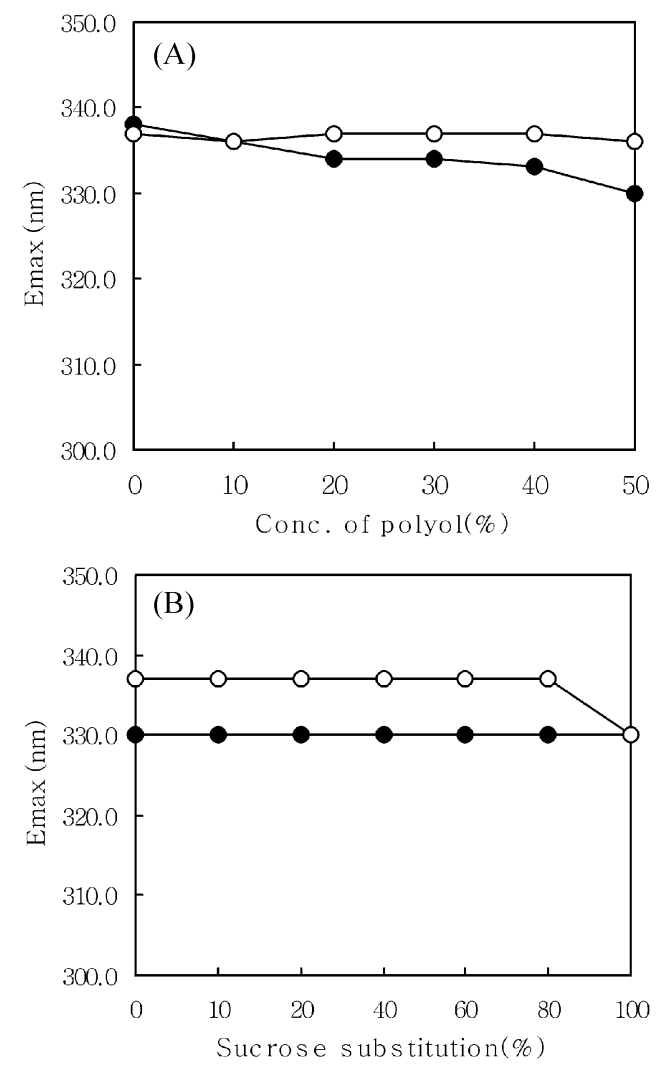

Fig. 7. Fluorescence emission spectral changes of $\operatorname{IgY}$ by polyol (a), or sucrose substitution for polyol (b) at $\mathrm{pH}$ 3. Sorbitol (O) or xylitol $(\bigcirc)$ was used as polyol. Total sugar concentration was 50\%. Emax was the emission peak, when excited at $296 \mathrm{~nm}$.

interactions. Gekko et al. (1999) reported that the stabilizing effects of polyols would increase if the polyol chain length was increased. Xylitol shows less viscosity than sorbitol at the same concentration (Marie and Piggott, 1991). For these reasons, xylitol may not suppress the acid-induced inactivation of $\mathrm{IgY}$.

In conclusion, the IgY stability at $\mathrm{pH} 3$ was considerably improved using high concentrations of sorbitol in solution. Sorbitol prevented the partial exposure of tryptophan residues, which resulted in the enhancement of IgY stability. However, xylitol could not suppress the acid-induced inactivation. These results suggest that sorbitol may be useful in stabilizing IgY at low $\mathrm{pH}$. Therefore, IgY could potentially be applied in highacid food products and extensively used for protection against H. pyroli infection.

Acknowledgments This study was supported by a grant (20000218) from the Soonchunhyang University in 2000.

\section{References}

Akita, E. M. and Nakai, S. (1993) Comparison of four purification methods for the production of immunoglobulins from eggs laid by hens immunized with an enterotoxicogenic E. coli strain. $J$. 
Immunol. Methods 160, 207-214.

Benedict, A. A. (1979) Immunoglobulin characteristics; in Biological handbook III, Altman, P. L. and Katz, D. D. (eds.), pp. 658-661, Federation of American Societies for Experimental Biology, Bethesda, Maryland.

Cho, Y. and Song, K. B. (2000) Effect of $\gamma$-irradiation on the molecular properties of bovine serum albumin and $\beta$ lactoglobulin. J. Biochem. Mol. Biol. 33, 133-137.

Chiba, N., Rao, B. V., Rademaker, J. W. and Hunt, R. H. (1992) Meta-analysis of the efficacy of antibiotic therapy in eradicating Helicobacter pyroli. Am. J. Gastroenterol. 87, 17161727.

Dunn, B. E., Cohen, H. and Blaser, M. J. (1997) Helicobacter pyroli. Clin. Microbiol. Rev. 10. 720-741.

Ernst, P. B. and Gold, B. D. (2000) The disease spectrum of Helicobacter pyroli: the immunopathogenesis of gastroduodenal ulcer and gastric cancer. Аnnu. Rev. Microbiol. 54, 615-640.

Gekko, K. (1981) Mechanism of polyol-induced protein stabilization: solubility of amino acids and diglycine in aqueous polyol solutions. J. Biochem. 90, 1633-1641.

Gekko, K. and Timasheff, S. N. (1981) Mechanism of protein stabilization by glycerol: preferential hydration in glycerolwater mixture. Biochemistry 20, 4667-4676.

Gekko, K., Li, X. and Makino, S. (1999) Competing effect of polyols on the thermal stability and gelation of soy protein. Biosci. Biotech. Biochem. 63, 2208-2211.

Giese, J. H. (1993) Alternative sweeteners and bulking agents. Food Tech. 47, 114-126.

Goodwin, C. S., Mendall, M. M. and Northfield, T. C. (1997) Helicobacter pyroli infection. Lancet 349, 265-269.

Hatta, H., Kim, M. and Yamamoto, T. (1990) A novel method for hen egg yolk antibody, "IgY". Agri. Biol. Chem. 54, 2531-2535.

Hatta, H., Tsuda, K., Achachi, A., Kim, M., Yamamoto, T. and Ebina, T. (1993) Oral passive immunization effect of antirotavirus $\operatorname{IgY}$ and its behavior against proteolytic enzymes. Biosci. Biotech. Biochem. 57, 1077-1081.

Hatta, H., Tsukuda, K., Ozeki, M., Kim., M., Yamamoto, T., Otake, S., Hirasawa, M., Katz, J., Childers, N. K. and Michalek, S. M. (1997) Passive immunization against dental plague formation in humans: effect of a mouth rinse containing egg yolk antibodies (IgY) specific to Streptococcus mutans. Caries Res. 31, 268-274.

Higgins, D. A. (1975) Physical and chemical properties of fowl immunoglobulins. Vet. Bull. 33, 609-619.

Japanese Chemical Society (1986) Meneki Seikagaku Kenkyuho, Tokyo Kagakudojin, Tokyo.

Kwack, K. (2000) A new purification method for the Fab and $\mathrm{F}(\mathrm{ab}$ ')2 fragment of $145-2 \mathrm{C} 11$, hamster anti-mouse $\mathrm{CD} 3 \mathrm{e}$ antibody. J. Biochem. Mol. Biol. 33, 188-192.

Larsson, A., Balow, R. M., Linda, T. L. and Forsberg, P. O. (1988) Chicken antibodies: taking advantage of evolution a review. Poultry Sci. 72, 1807-1812.

Leslie, G. A. and Clem, L. W. (1969) Phylogeny of immunoglobulin structure and function: immunoglobulins of the chicken. J. Exp. Med. 130, 1337-1352.

Ling, T. K., Cheng, A. F. B., Sung, J. Y., Yiu, P. Y. and Chung, S. C. (1996) An increase in Helicobacter pyroli strains resistance to metronidazole: a five-year study. Helicobacter 1, 57-61.

Lösch, U., Schranner, I., Wanke, R. and Jurgens, L. (1988) The chicken egg, an antibody source. J. Vet. Med. B. 33, 609-619.

Marie, S. and Piggott, J. R. (1991) Handbook of Sweetner. Avi., New York.

Mattila, P. T., Svanberg, M. J., Makinen, K. K. and Knuttila, M. E. (1996) Dietary xylitol, sorbitol and D-mannitol but not erythritol retard bone resorption in rats. J. Nutri. 126, 18651870.

D'Farrelly, C., Branton, D. and Wanke, C. A. (1992) Oral ingestion of egg yolk immunoglobulin from hens immunized with an enterotoxicogenic Escherichia coli strain prevents diarrhea in rabbits challenged with the same strain. Am. Soc. Microbiol. 60, 2593-2597.

Otake, S., Nishihara, M., Makimura, M., Hatta, H., Kim., M., Yamamoto, T. and Hirasawa, T. (1991) Protection of rats against dental caries by passive immunization with hen-egg yolk antibody (IgY) J. Dental Res. 70, 162-166.

Palmer, J. L., Nisonoff, A. and Holde, K. E. V. (1963) Dissociation of rabbit gamma globulin into subunits by reduction and acidification. Proc. Natl. Acad. Sci. USA 50, 314-321.

Parvari, R., Avivi, A., Lentner, F., Ziv, E., Tel-Or, S., Burstein, Y. and Schetcher, I. (1988) Chicken immunoglobulin G-heavy chains: limited $\mathrm{VH}$ gene repertoire, combinational diversification by $\mathrm{D}$ gene segments and evolution of the heavy chain locus. EMBO J. 7, 739-744.

Polson, A., Von Wetchmar, B. and Fazakerly, G. (1980) Isolation of viral IgY antibodies from yolks of immunized hens. Immunol. Commun. 9, 475-493.

Reyanud, C.-A., Dahan, A., Anquez, V. and Weill, J.-C. (1989) Somatic hyperconversion diversifies the single $\mathrm{VH}$ gene of the chicken with a high incidence in the D region. Cell 59, 171-183.

Rose, M. E., Orlands, E. and Buttress, N. (1974) Immunoglobulin classes in the hens egg: their segregation in yolk and white. Eur. J. Immunol. 4, 521-523.

Rose, M. E. and Orlands, E. (1981) Immunoglobulins in the egg, embryo and young chick. Dev. Conm. Immunol. 5, 15-20.

Smith, D. J., King, W. F. and Godiska, R. (2001) Passive transfer of immunoglobulin Y antibody to Streptococcus mutans glucan binding protein $\mathrm{B}$ can confer protection against experimental dental caries. Infec. Immunity 69, 3135-3142.

Tenenhouse, H. S. and Deutsch, H. F. (1966) Some physical properties of chicken globulins and their pepsin and papain digestion products. Immunochemistry 3, 11-20.

Thompson, C. B. and Nieman, P. E. Somatic diversification of the chicken immunoglobulins light chain gene is limited to the rearranged variable gene segment. Cell 48, 369-378.

Warr, G. M., Magor, K. E. and Higgins, D. A. (1995) IgY; clues to the origin of modern antibodies. Immunol. Today 16, 392398.

Weber, K. and Osborn, M. (1969) The reliability of molecular weight determined by dodecyl sulfate polyacrylamide gel electrophoresis. J. Biol. Chem. 244, 4406-4412.

Yang, J., Jin, Z., Yu, Q., Yang, T., Wang, H. and Liu, L. (1997) The selective recognition of antibody $\operatorname{IgY}$ for digestive system cancers. Chin. J. Biotechnol. 13, 85-90.

Yoelken, R. H., Leister, F., Wee, S. -B., Miscuff, R. and Vonderfecht, S. (1988) Antibodies to rotaviruses in chickens egg: a potential source of anti-viral immunoglobulins suitable for human consumption. Pediatrics 81, 291-295. 